\title{
Defoliation Effects on Herbage Production and Root Growth of Wet Meadow Forage Species
}

\author{
Jerry D. Volesky, ${ }^{1}$ Walter H. Schacht, ${ }^{2}$ Ann E. Koehler, ${ }^{3}$ Erin Blankenship, ${ }^{4}$ and Patrick E. Reece \\ Authors are ${ }^{1}$ Professor, University of Nebraska-Lincoln, West Central Research and Extension Center, North Platte, NE 69101, USA; ${ }^{2}$ Professor, \\ Department of Agronomy and Horticulture, University of Nebraska-Lincoln, Lincoln, NE 68583, USA; ${ }^{3}$ Research Analyst, University of \\ Nebraska-Lincoln, Panhandle Research and Extension Center, Scottsbluff, NE 69361, USA; ${ }^{4}$ Associate Professor, Department of Statistics, University of \\ Nebraska-Lincoln, Lincoln, NE 68583, USA; and ${ }^{5}$ Former Professor, University of Nebraska-Lincoln, Panhandle Research and Extension Center, \\ Scottsbluff, NE 69361, USA.
}

\begin{abstract}
Root growth is important to the competitive ability of plants, and understanding how herbage defoliation affects root growth has implications for development of management strategies. Objectives were to determine the effects of defoliation intensity and frequency on root characteristics and herbage production of slender wheatgrass (Elymus trachycaulus [Link.] Shinners), Nebraska sedge (Carex nebrascensis C. Dewey), and "Steadfast" birdsfoot trefoil (Lotus corniculatus L.). Plants of each species were transplanted into containers that had been placed in the ground at wet meadow field sites the prior year. There were eight replications of a control and five defoliation treatments, which were combinations of different frequencies (two or five times) and intensities (light or heavy) and haying. Treatments were applied for a single growing season, and aboveground biomass was collected. Containers were extracted in October, and plant crowns, rhizomes, and roots were separated from the soil. Defoliation treatment did not affect total root weight, length, and surface area of Nebraska sedge or birdsfoot trefoil $(P>0.10)$. Slender wheatgrass total root weight was less when defoliated five times $\left(4.46 \mathrm{~g} \cdot\right.$ container $\left.^{-1}\right)$ than when defoliated twice $\left(6.62 \mathrm{~g} \cdot\right.$ container $\left.^{-1}\right)$ during the growing season. More frequent defoliation of slender wheatgrass also reduced length $(20 \%)$ and surface area $(21 \%)$ compared to less frequent defoliation. However, defoliation frequency did not affect aboveground biomass. Defoliation intensity did not affect aboveground production or root characteristics of the three species. Abundant soil moisture in meadows likely buffers negative effects of defoliation. For all species, two defoliation events (e.g., haying followed by grazing) does not appear to negatively affect root growth and herbage production.
\end{abstract}

\section{Resumen}

El crecimiento radicular es importante en la habilidad de las plantas para competir y, entender como el efecto de defoliación afecta el crecimiento radicular y las implicaciones en implementar de estrategias de manejo. Los objetivos de este estudio fueron determinar el efecto de la intensidad y frecuencia de defoliación en las características y producción herbácea del triguillo delgado (Elymustrachycaulus [Link.] Shinners), junco de Nebraska (Carex nebrascensis C. Dewey), y trébol pata de pájaro (Lotus corniculatus L.). Plantas de cada especie fueron trasplantadas en contenedores que se pusieron con un año de anticipación en el suelo en sitios de praderas húmedas. Hubo ocho repeticiones, un control y cinco tratamientos de defoliación que se combinaron con diferentes frecuencias (de dos a cinco veces) e intensidades (leve e intensa) y henificación. Los tratamientos se realizaron una sola temporada de crecimiento y se colecto la biomasa aérea. Los contenedores se retiraron en octubre y la corona, rizomas y raíces de las plantas se separaron del suelo. El tratamiento de defoliación no afecto el peso total, extensión y superficie de la raíz del junco de Nebraska y trébol pata de pájaro $(P>0.10)$. El peso total de la raíz del triguillo delgado fue menor cuando se defolio cinco veces $\left(4.46 \mathrm{~g} \cdot\right.$ contenedor $\left.^{-1}\right)$ qué cuando se defolio dos veces $\left(6.62 \mathrm{~g} \cdot\right.$ contenedor $\left.^{-1}\right)$ durante la época de crecimiento. También, la frecuencia de defoliación del triguillo delgado reduce la extensión (20\%) y superficie (21\%) de la raíz comparado con defoliaciones menos frecuentes. Sin embargo, la frecuencia de defoliación no afecto la producción de biomasa aérea. La intensidad de defoliación no afecto la producción aérea ni las características de la raíz de las tres especies. La abundancia de humedad en el suelo en las praderas probablemente amortigua el efecto negativo de la defoliación. Para todas las especies, dos eventos de defoliación (ej. henificación seguida del pastoreo) aparentemente no afecta negativamente el crecimiento de la raíz y la producción herbácea.

Key Words: birdsfoot trefoil, defoliation frequency, defoliation intensity, Nebraska sedge, root distribution, root length, root surface area, root weight, slender wheatgrass

\section{INTRODUCTION}

A contribution of the University of Nebraska Agricultural Research Division, supported in part by funds provided through the Hatch Act. Additional support was provided by University of Nebraska Foundation Sampson Range and Pasture Endowment.

Correspondence: Jerry D. Volesky, West Central Research and Extension Center, 402 West State Farm Rd, North Platte, NE 69101. Email: jvolesky1@unl.edu

Manuscript received 12 January 2010; manuscript accepted 18 April 2011.
Understanding defoliation and plant growth interactions has direct application in the development of sustainable management strategies for grasslands. Plant response to defoliation has been the objective of numerous research studies (Jameson 1963; Belesky 1986; Jones and Nielson 1993). While many of these studies have concentrated on aboveground plant or plant 
community characteristics, less research has been conducted where root growth characteristics have been studied. Weaver (1930) and Ellison (1960) indicated that root growth was important to the competitive ability of plants. When root growth is reduced, the ability of plants to obtain water and nutrients is also reduced. Engel et al. (1998) found that sand bluestem (Andropogon gerardii var. paucipilus [Nash] Fern.), root weight, surface area, and length were reduced when defoliation occurred in June or July and to a greater extent when defoliated multiple times during June through August. The timing coincides with stem elongation of this warm-season upland species.

General rooting characteristics in wet meadow plant communities have been studied and show exceptionally high root mass compared to other graminoid plant communities (Manning et al. 1989). Moore and Rhoades (1966) concluded that there is a link between the large mass of surface roots and low soil bulk density in wet meadows. On riparian meadow systems, the large root mass can be critical in stabilizing stream channel banks (Smith 1976). However, research is lacking on root response to defoliation for individual species in a wet meadow environment. In the Nebraska Sandhills, introduced cool-season grasses and legumes, along with native sedge and rush species, dominate most meadow plant communities. These wet meadows are highly productive and are the primary source of hay fed to cattle during the dormant season (Coady and Clark 1993). Haying typically occurs in July and grazing of regrowth after haying occurs in fall. Grazing of meadows throughout the growing season or during specific periods is another possible use strategy for the resource (Volesky et al. 2002, 2004).

The objectives of this study were to determine the effects of defoliation intensity and frequency on herbage production and root characteristics of slender wheatgrass (Elymus trachycaulus [Link.] Shinners), Nebraska sedge (Carex nebrascensis C. Dewey), and "Steadfast" birdsfoot trefoil (Lotus corniculatus L.). Plant nomenclature follows Kaul et al. (2006). Slender wheatgrass and Nebraska sedge are important cool-season species on many meadow sites, and birdsfoot trefoil is one of several legumes used to enhance meadow forage quality. We hypothesized that increasing defoliation intensity and frequency would negatively affect aboveground herbage production and root weight, length, and surface area of the three species within the year of defoliation.

\section{MATERIALS AND METHODS}

\section{Study Area and Plant Material}

The study was conducted during 1999 and 2000 at the University of Nebraska, Gudmundsen Sandhills Laboratory, $11 \mathrm{~km}$ northeast of Whitman, Nebraska (lat $42^{\circ} 04^{\prime} \mathrm{N}$, long $101^{\circ} 26^{\prime} \mathrm{W}$, elevation $\left.=1075 \mathrm{~m}\right)$. Mean annual precipitation at the location is $460 \mathrm{~mm}$. The average January temperature is $-6.2^{\circ} \mathrm{C}$, and the average July temperature is $22.3^{\circ} \mathrm{C}$. Annual precipitation was $335 \mathrm{~mm}$ in 1999 and $455 \mathrm{~mm}$ in 2000 . Average growing season (April through October) precipitation is $364 \mathrm{~mm}$, and $320 \mathrm{~mm}$ fell in 1999 and $388 \mathrm{~mm}$ in 2000 .

During the spring of 1999, individual plants of slender wheatgrass (E. trachycaulus [Link] Gould ex Shinners),
Nebraska sedge (C. nebrascensis C. Dewey), and "Steadfast" birdsfoot trefoil (L. corniculatus L.) were grown from seed in a greenhouse. Seed of slender wheatgrass and Nebraska sedge was collected the previous year from natural populations in a wet meadow at the Gudmundsen Sandhills Laboratory. Seed of birdsfoot trefoil was obtained from a commercial source. In late May, the seedlings were transplanted into containers placed in the ground at wet meadow field sites. The containers were polyvinyl chloride tubes measuring $100 \mathrm{~cm}$ in length by $15 \mathrm{~cm}$ in diameter (Engel et al. 1993). These containers were placed in the ground in 1998 using a tractor-mounted soil probe that extracted a core equal in size to the container. The intact soil core was placed into the container and then placed back in the hole. During the 1998 growing season, glyphosate herbicide was used to kill any existing vegetation growing in the containers. Prior to transplanting, any existing root material in the top $20 \mathrm{~cm}$ that had not decomposed was manually removed. The bottom of the containers had a porous wooden plug covered with nylon mesh to allow for water inflow and outflow and containment of the root system. Over $96 \%$ of transplants survived the initial planting and dead plants were replaced within $2 \mathrm{wk}$ of the initial planting.

For each species, 48 containers were arranged in a $6 \times 8$ grid with a $1-\mathrm{m}$ spacing between containers. Meadow sites for each species were chosen on the basis of degree of soil wetness, duration of flooding, and depth to water. Sites were similar to areas where the species were adapted under natural conditions. For Nebraska sedge, the location was classified as a wetland range site with the water table at or above the soil surface during May. For slender wheatgrass and birdsfoot trefoil, the locations were classified as subirrigated range sites with an average depth to water table of $60 \mathrm{~cm}$ for slender wheatgrass and $120 \mathrm{~cm}$ for birdsfoot trefoil. Soils at all sites were GannettLoup fine sandy loam (coarse loamy, mixed, mesic Typic Haplaquoll) derived from an eolian sand parent material.

\section{Defoliation Treatments}

The containerized plants were allowed to establish during the 1999 growing season. The experimental design was a randomized complete block with six treatments and eight replications. Blocking was assigned in the fall of 1999 and was based on total number of tillers per container for Nebraska sedge and slender wheatgrass and crown diameter for birdsfoot trefoil. Containers were considered the experimental unit. Treatments were applied in 2000 and included a control, defoliation that simulated haying, monthly (F-5) heavy or light defoliation, and May and September (F-2) heavy or light defoliation (Table 1).

Defoliation treatments were applied by hand clipping all tillers (parent and daughter) within the containers. Prior to clipping, tillers were counted in each container, and an average tiller height was determined. For light and heavy defoliation, herbage was clipped to levels based on postgrazing stubble height measured at light (148 animal unit days [AUD] ha ${ }^{-1}$ ) and heavy (444 AUD ha ${ }^{-1}$ ) stocking rates in a grazing trial (Volesky et al. 2004). The grazing trial was conducted on botanically similar wet meadow and had 2-d grazing periods occurring from May through September in combination with three stocking rates (Volesky et al. 2004). Clipping stubble 
Table 1. Defoliation treatment schedule and average percent weight of herbage removed for individual species under light, heavy, and haying defoliation regimes.

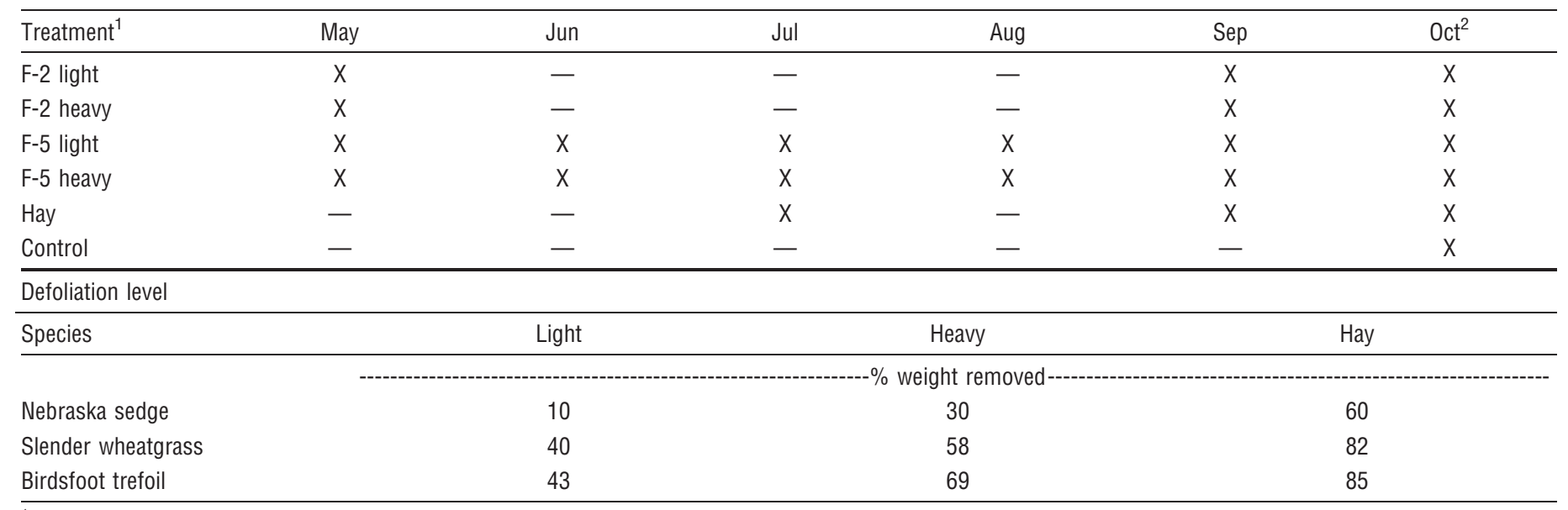

${ }^{1} \mathrm{~F}-2$ and $\mathrm{F}-5$ refers to growing season defoliation frequency

${ }^{2}$ October (end-of-season) defoliation was to ground level for all treatments.

height varied by month matching that measured in the grazing trial and ranged from $13.9 \mathrm{~cm}$ to $18.5 \mathrm{~cm}$ for light defoliation and from $8.1 \mathrm{~cm}$ to $11.6 \mathrm{~cm}$ for heavy defoliation. Defoliation for the hay treatment was to a $6-\mathrm{cm}$ stubble height in July and to an $8.1-\mathrm{cm}$ stubble height in September with the latter simulating grazing of regrowth after haying. The percent weight removed for the various stubble height treatments was estimated at each clipping date. This procedure involved collecting tillers of the three species growing in a wet meadow area adjacent to the containerized plant study site. At least 10 tillers were grouped to match the average preclipping height for the different treatments. These tillers were then clipped to the corresponding treatment stubble heights, and top and stubble portions separately bagged, dried, and weighed. Percent weight removed was calculated as top weight divided by total weight times 100. Average percent weight removed for the three species and defoliation levels are shown in Table 1 . Within defoliation level, percent weight removed differed among species because of differences in growth form. In late October 2000, herbage in all treatments was clipped to ground level and collected. Only current-year herbage growth was collected during all clipping events. Number of tillers of Nebraska sedge and slender wheatgrass per container was counted. All clipped herbage samples were oven dried at $60^{\circ} \mathrm{C}$ to a constant weight. Total herbage production was calculated as the sum of the October clipping plus that removed during the designated May through September clippings.

\section{Root Analysis}

Following the final clipping, containers were extracted from the ground using a hydraulic lift system. Containers were opened by making lengthwise cuts on opposite sides using a circular saw and intact soil columns removed. Soil columns were divided into four $25-\mathrm{cm}$ sections and plant crowns, rhizomes, and roots separated from the soil by hand washing. Rhizomes and roots were separated from crowns. Cleaned rhizome and root sections were then bagged and frozen for later analysis. Birdsfoot trefoil did not produce identifiable rhizomes, but crown material was saved and oven dried at $60^{\circ} \mathrm{C}$ to a constant weight.
Data on root length, surface area, and diameter were collected using the WinRHIZO LA-1600 digitized scanning system (Regent Instruments Inc., Quebec City, Quebec, Canada). This system includes analysis software (ver. 4.1c) and hardware. The WinRHIZO system has been successfully used for root analysis of field crop (Costa et al. 2002) and grassland species (Derner et al. 2001; Mousel et al. 2005). Root samples were placed in a Plexiglas tray in 4-5 $\mathrm{mm}$ of water for scanning. Scanning resolution was set to $400 \mathrm{dpi}$, and images were captured on a Windows-based computer for analysis using the WinRHIZO software. The software was configured to perform root analyses by four diameter classes. Diameter classes were $0-1 \mathrm{~mm}, 1-2$ $\mathrm{mm}, 2-3 \mathrm{~mm}$, and $>3 \mathrm{~mm}$ for Nebraska sedge and birdsfoot trefoil and $0-0.25 \mathrm{~mm}, 0.25-0.50 \mathrm{~mm}, 0.50-1 \mathrm{~mm}$, and $>1 \mathrm{~mm}$ for slender wheatgrass. Following scanning, root material was oven dried at $60^{\circ} \mathrm{C}$ to a constant weight.

\section{Statistical Analysis}

All aboveground herbage and root data were analyzed using mixed-model analysis of variance (ANOVA) implemented in SAS PROC MIXED (Littell et al. 2006) with the blocks considered as a random effect. Because of growing site differences for each species, data were analyzed by species and no comparisons made among species. Log-transformed root characteristic data were analyzed using a repeatedmeasures ANOVA, with observations on each container taken repeatedly at each depth increment. For repeated-measures analyses, which were implemented in SAS PROC GLIMMIX (Littell et al. 2006), the best covariance structure for each response variable was selected using the Akaike information criterion. Preplanned contrasts of treatment effects were heavy vs. light defoliation, defoliation frequency 2 vs. 5, haying vs. light defoliation, haying vs. heavy defoliation, and control vs. all defoliation treatments. Main effects for root characteristics included depth increment and root diameter classes for the different species. However, none of the root diameter class analyses showed consistent or biologically significant treatment effects. Effects were considered significant at $P \leq 0.10$ for all analyses unless otherwise stated. 
Table 2. Defoliation treatment effects on herbage harvested by date and total aboveground herbage production for Nebraska sedge plants.

\begin{tabular}{|c|c|c|c|c|c|c|c|}
\hline Treatment $^{1}$ & May & Jun & Jul & Aug & Sep & $0 \mathrm{ct}^{2}$ & Total \pm SE \\
\hline & ----- &  & ----- & ----- & & & \\
\hline F-2 light & 0.09 & - & - & - & 0.21 & 3.74 & $4.04 \pm 0.57$ \\
\hline F-2 heavy & 0.24 & - & - & - & 0.88 & 3.79 & $4.92 \pm 0.68$ \\
\hline F-5 light & 0.14 & 0.10 & 0.03 & 0.12 & 0.07 & 4.21 & $4.66 \pm 0.29$ \\
\hline F-5 heavy & 0.35 & 0.27 & 0.22 & 0.41 & 0.33 & 3.39 & $4.97 \pm 0.50$ \\
\hline Hay & - & - & 1.39 & - & 0.76 & 3.69 & $5.83 \pm 0.63$ \\
\hline \multirow[t]{7}{*}{ Control } & - & - & - & - & - & 4.74 & $4.74 \pm 0.47$ \\
\hline & & & & & & Contrasts & ----- $(\operatorname{Pr}>F)$ \\
\hline & & & & & & Heavy vs. light & 0.20 \\
\hline & & & & & & Frequency 2 vs. 5 & 0.47 \\
\hline & & & & & & Hay vs. light & 0.01 \\
\hline & & & & & & Hay vs. heavy & 0.12 \\
\hline & & & & & & Control vs. all others & 0.78 \\
\hline
\end{tabular}

${ }^{1} \mathrm{~F}-2$ and F-5 refers to growing season defoliation frequency. Light, heavy, and hay treatments removed $10 \%$, 30\%, and $60 \%$ of herbage by weight, respectively.

${ }^{2}$ October (end-of-season) defoliation was to ground level for all treatments.

\section{RESULTS AND DISCUSSION}

\section{Aboveground Herbage Production}

Total aboveground herbage production averaged 4.86, 8.93, and $18.41 \mathrm{~g} \cdot$ container $^{-1}$ for Nebraska sedge, slender wheatgrass, and birdsfoot trefoil, respectively. Birdsfoot trefoil did maintain consistent growth after defoliation throughout the growing season, whereas growth of the cool-season graminoids slowed during mid- and late summer. The effect of defoliation treatment on total production varied by species (Tables 2-4). Total production was greater under the haying treatment compared to light defoliation for all species $(P<0.05)$. For birdsfoot trefoil, production was greater with haying vs. heavy or light defoliation, and production was also greater with the monthly defoliation (F-5) vs. May and September (F-2) defoliation. All species had reached a reproductive stage of growth at the time of our haying treatment (July). This indicates that timing of defoliation associated with the hay treatment was important in realizing greater harvested yield. The effect of allowing initial spring growth to reach advanced stages of maturity has been shown to increase the season total yield for other species such as orchardgrass (Dactylis glomerata L.; Kunelius et al. 1974) and reed canarygrass (Phalaris arundinacea L.; Mislevy et al. 1977). For all species, intensity of defoliation (heavy vs. light) did not affect total production $(P>0.10)$. In a quantitative review of research, Ferraro and Oesterheld (2002) reported that intensity had little impact on plant response to defoliation. However, defoliation frequency was a more important variable. It was observed that more negative effects were evident with high frequency of defoliation or short recovery times (Ferraro and Oesterheld 2002).

For slender wheatgrass and birdsfoot trefoil, total aboveground production was greater for all defoliation treatments compared to the control. Senescing herbage of control plants may have contributed to lower total production. Boyd and Svejcar (2004) also observed this response on mixed grass, sedge, and rush riparian meadow communities. For Nebraska sedge production, the contrast of the control vs. all defoliation treatments was not significant $(P>0.10$; Table 2$)$. Martin and
Chambers (2001) also reported that clipping did not affect biomass of this species. In a sedge-dominated riparian community, Clary (1995) reported that defoliation to a $5-\mathrm{cm}$ stubble height with associated trampling compaction will often reduce future sedge biomass production.

Defoliation treatments had no effect on end-of-season tiller density of Nebraska sedge or slender wheatgrass $(P>0.10)$. Both species had emergence of new tillers during late summer and fall. From May through July, Nebraska sedge had an average of 15.5 tillers $\cdot$ container $^{-1}$ and increased to 22.7 tillers $\cdot$ container $^{-1}$ in September and October. For slender wheatgrass, there was an average of 31 tillers $\cdot$ container $^{-1}$ during the May through August sampling and an increase to 43 tillers $\cdot$ container $^{-1}$ in September and 56 tillers $\cdot$ container $^{-1}$ in October. The lack of correlation between treatment effects on herbage production and treatment effects on tiller density indicates that differences in tiller height and weight were present. Although both species did have substantial development of new tillers from the original parent plant, the containers likely limited spatial expansion of new tillers and possibly their growth potential.

Martin and Chambers (2001) also reported that clipping did not affect tillering of Nebraska sedge. However, tillering of this species increased when neighboring Kentucky bluegrass (Poa pratensis L.) was removed. In Sandhills wet meadows, specific grazing management practices have been found to increase Kentucky bluegrass (Volesky et al. 2004), and that may be more responsible for limiting tiller expansion of Nebraska sedge than defoliation.

\section{Root Characteristics}

Root Distribution. There was a significant depth increment effect on root weight, length, and surface area for each of the three species $(P<0.01 ;$ Figs. 1a-1c). Sixty-three or more percent of Nebraska sedge root weight, length, and surface area was present in the surface $25 \mathrm{~cm}$ with only $1-2 \%$ observed at the 76-1000 cm-depth increment. Seventy percent, 59\%, and $62 \%$ of slender wheatgrass root weight, length, and surface 
Table 3. Defoliation treatment effects on herbage harvested by date and total aboveground herbage production for slender wheatgrass plants.

\begin{tabular}{|c|c|c|c|c|c|c|c|}
\hline Treatment $^{1}$ & May & Jun & Jul & Aug & Sep & $0 \mathrm{ct}^{2}$ & Total \pm SE \\
\hline & 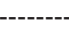 & 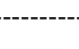 & ------ & cor & ------ & 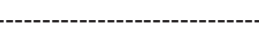 & - \\
\hline F-2 light & 0.81 & - & - & - & 2.32 & 4.86 & $7.99 \pm 0.75$ \\
\hline F-2 heavy & 1.96 & - & - & - & 3.37 & 4.13 & $9.46 \pm 0.58$ \\
\hline F-5 light & 0.89 & 1.03 & 0.37 & 0.92 & 0.34 & 5.21 & $8.76 \pm 0.74$ \\
\hline F-5 heavy & 1.96 & 0.90 & 0.63 & 0.91 & 0.87 & 4.20 & $9.47 \pm 0.33$ \\
\hline Hay & - & - & 5.37 & - & 0.80 & 4.05 & $10.23 \pm 1.08$ \\
\hline \multirow[t]{7}{*}{ Control } & - & - & - & - & - & 7.65 & $7.65 \pm 0.59$ \\
\hline & & & & & & Contrasts & $(\operatorname{Pr}>F)^{-\cdots}$ \\
\hline & & & & & & Heavy vs. light & 0.11 \\
\hline & & & & & & Frequency 2 vs. 5 & 0.55 \\
\hline & & & & & & Hay vs. light & 0.03 \\
\hline & & & & & & Hay vs. heavy & 0.35 \\
\hline & & & & & & Control vs. all others & 0.04 \\
\hline
\end{tabular}

${ }^{1} \mathrm{~F}-2$ and F-5 refers to growing season defoliation frequency. Light, heavy, and hay treatments removed $40 \%$, $58 \%$, and $82 \%$ of herbage by weight, respectively.

${ }^{2}$ October (end-of-season) defoliation was to ground level for all treatments.

area, respectively, were in the surface $25 \mathrm{~cm}$. Although the majority of birdsfoot trefoil roots were in the surface $25 \mathrm{~cm}$, there was considerable root growth at the 76-100-cm depth increment, with accumulation of roots at the meshed bottom of the container. This indicates that birdsfoot trefoil roots would have extended beyond $100 \mathrm{~cm}$ in depth, likely to access more water. The site where the birdsfoot trefoil containers were installed did have the greatest depth to the water table (about $120 \mathrm{~cm}$ ) compared to Nebraska sedge and slender wheatgrass. On a Nebraska Sandhills wet meadow dominated by cool-season graminoids, Moore and Rhoades (1966) reported a similar vertical distribution of total root weight. Their work included smaller depth increments, and they were able to estimate that $51 \%$ of the total root weight occurred in the top $5 \mathrm{~cm}$.

Differences in soil texture, fertility, and organic matter content through the profile were reflective of root distribution patterns. Study site soils at $0 \mathrm{~cm}$ to $35 \mathrm{~cm}$ included silt loams and fine sandy loams with moderate to high organic matter content (3$5 \%$ ). Soil texture at depths greater than $35 \mathrm{~cm}$ was characterized as loamy fine sand or fine sands with low organic matter. Moore and Rhoades (1966) directly linked the abundance of root weight in the upper soil profile with low bulk density values and high values for cation exchange capacity, organic matter, total nitrogen, and total phosphorus.

Root Weight, Length, and Surface Area. Defoliation treatment did not affect total root weight, length, and surface area of Nebraska sedge or birdsfoot trefoil $(P>0.10$; Table 5). Nebraska sedge root weight, length, and surface area in the 51-75-cm and 76-100-cm depth increments was less under the haying treatment compared to light defoliation. Although this was statistically significant, the amount of root at those depths accounted for only $8 \%$ of the total root mass (Fig. 1a). For birdsfoot trefoil, there was greater root weight and surface area at the $76-100-\mathrm{cm}$ depth increment of the control compared to all defoliated treatments $(P=0.03)$. This variety of birdsfoot trefoil ("Steadfast") has been reported to produce reproductive rhizomes but expression of this trait is affected by environment

Table 4. Defoliation treatment effects on herbage harvested by date and total aboveground herbage production for birdsfoot trefoil plants.

\begin{tabular}{|c|c|c|c|c|c|c|c|}
\hline Treatment $^{1}$ & May & Jun & Jul & Aug & Sep & $0 \mathrm{ct}{ }^{2}$ & Total \pm SE \\
\hline & ------ & ----- & -------- & conta & --- & - & -------------------- \\
\hline F-2 light & 0.91 & - & - & - & 3.57 & 9.60 & $14.08 \pm 0.54$ \\
\hline F-2 heavy & 1.65 & - & - & - & 6.17 & 7.94 & $15.76 \pm 1.95$ \\
\hline F-5 light & 0.86 & 2.75 & 2.96 & 3.15 & 1.59 & 10.18 & $21.49 \pm 1.91$ \\
\hline F-5 heavy & 1.93 & 3.71 & 5.83 & 2.12 & 1.97 & 6.43 & $21.98 \pm 2.67$ \\
\hline Hay & - & - & 14.15 & - & 3.40 & 6.86 & $24.41 \pm 2.91$ \\
\hline \multirow[t]{7}{*}{ Control } & - & - & - & - & - & 12.71 & $12.71 \pm 1.44$ \\
\hline & & & & & & Contrasts & --- $(\operatorname{Pr}>F)$------- \\
\hline & & & & & & Heavy vs. light & 0.54 \\
\hline & & & & & & Frequency 2 vs. 5 & 0.01 \\
\hline & & & & & & Hay vs. light & 0.01 \\
\hline & & & & & & Hay vs. heavy & 0.01 \\
\hline & & & & & & Control vs. all others & 0.01 \\
\hline
\end{tabular}

\footnotetext{
${ }^{1} \mathrm{~F}-2$ and F-5 refers to growing season defoliation frequency. Light, heavy, and hay treatments removed $43 \%, 69 \%$, and $85 \%$ of herbage by weight, respectively.
}

${ }^{2}$ October (end-of-season) defoliation was to ground level for all treatments. 

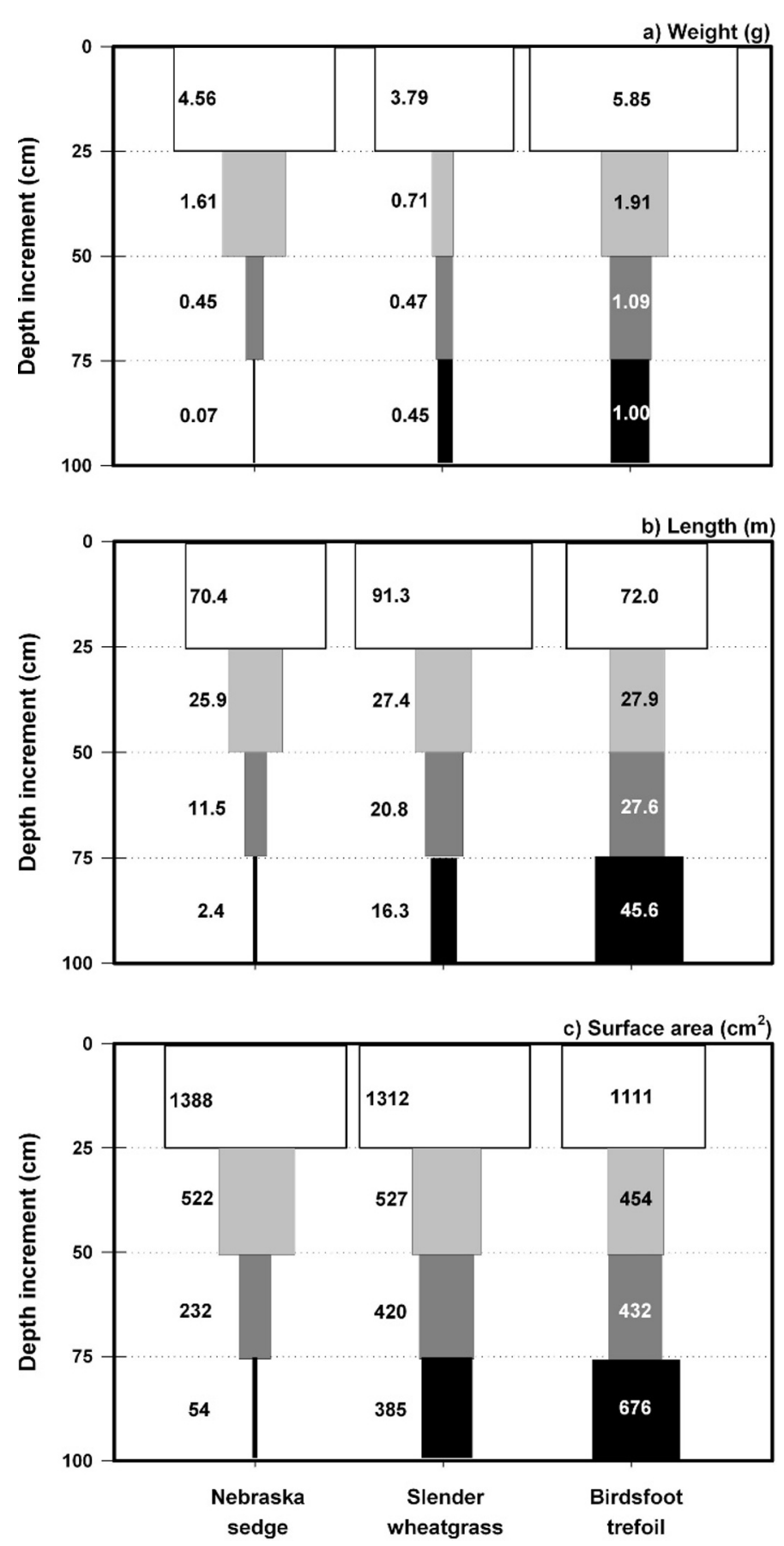

Figure 1. Distribution of root weight (a), length (b), and surface area (c) of Nebraska sedge, slender wheatgrass, and birdsfoot trefoil plants at four depth increments. Data are averaged over all defoliation treatments.

(Beuseclinck and Steiner 1995; Beuseclinck et al. 2005). We did not observe nor were able to specifically identify any of the belowground structures as a rhizome. Rather than a single primary tap root, most plants contained multiple, larger intertwined primary roots, extending from the crown. Birdsfoot trefoil crown weight averaged $4.21 \pm 0.61 \mathrm{~g}$, and defoliation treatment contrasts were not significant $(P>0.10)$.

Slender wheatgrass total root weight under F-5 defoliation $\left(4.46 \mathrm{~g} \cdot\right.$ container $\left.^{-1}\right)$ was significantly less than F-2 (6.62 $\mathrm{g} \cdot$ container $^{-1}$; Table 5). More frequent defoliation (F-5) of slender wheatgrass also reduced length $(20 \%)$ and surface area $(21 \%)$ compared to less frequent defoliation (F-2). This effect was found within all four root diameter classes and in the 0-25$\mathrm{cm}, 26-50-\mathrm{cm}$, and $51-75-\mathrm{cm}$ depth increments.

We were not able to find specific published literature reporting defoliation effects on root response for these species. Nebraska sedge has been reported to withstand a high degree of defoliation without being seriously damaged, in part because it has a relatively low ratio of reproductive to vegetative tillers (Ratliff 1983). Our levels of defoliation were based on stubble height from a previous grazing study. For Nebraska sedge, light and heavy defoliation levels removed only $10 \%$ and $30 \%$ of herbage by weight, respectively (Table 1 ), indicating that a large proportion of the tiller weight was near the ground surface. Steele et al. (1984) found total nonstructural carbohydrate levels of Nebraska sedge rhizomes and shoots to be lowest during early growth and highest after anthesis. Correspondingly, it was suggested that defoliation during early growth would be detrimental to plant growth. Lamman (1994) found that moderate defoliation ( $60 \%$ of current herbage) of Nebraska sedge annually for $3 \mathrm{yr}$ had little effect on leaf length.

Although our plants were grown in containers, our estimates of root production were comparable to that reported in the literature for meadow plant communities. On sedge-dominated meadows in Colorado, Fisk et al. (1998) reported $364 \mathrm{~g} \cdot \mathrm{m}^{-2}$ root production (to a $15-\mathrm{cm}$ depth), and Kiley and Schneider (2005) found production values of about $500 \mathrm{~g} \cdot \mathrm{m}^{-2}$ (to a $30-\mathrm{cm}$ depth) for mixed sedge communities in a riparian system in New York. On this basis, root production for our containerized plants (to a $100-\mathrm{cm}$ depth) was $366 \mathrm{~g} \cdot \mathrm{m}^{-2}$ for Nebraska sedge, $300 \mathrm{~g} \cdot \mathrm{m}^{-2}$ for slender wheatgrass, and $540 \mathrm{~g} \cdot \mathrm{m}^{-2}$ for birdsfoot trefoil.

In several cases, treatment effects on root characteristics were not consistent with effects on aboveground herbage production. More frequent defoliation, for example, reduced slender wheatgrass root growth but did not affect herbage production. Depending on the environment, some species are able to maintain or even increase root respiration and nutrient absorption following a single defoliation, but multiple defoliation reduces root growth (Chapin and Slack 1979). It has been observed that rapidly growing plants in high-fertility environments will reduce root growth and elongation, root respiration, and nutrient absorption following defoliation of $50 \%$ or more of the shoots (Crider 1955). For all species, the haying treatment resulted in greater herbage production than light defoliation at either F-2 or F-5, but there were no effects on root growth. For slender wheatgrass, it is possible that effects of reduced root growth may not be reflected in herbage production until the following year. Jameson (1963) and Engel et al. (1998) also suggested that defoliation may need to be applied more than one season to evaluate the response of aboveground production.

Rhizome Weight and Length. Defoliation treatments did not affect rhizome weight or length of Nebraska sedge $(P>0.10$; Table 6). Average rhizome weight was $1.36 \mathrm{~g} \cdot$ container $^{-1}$, and length was $1.20 \mathrm{~m}$. Nebraska sedge rhizome weight was $20 \%$ of that observed for roots.

The contrast of F-2 vs. F-5 was significant for slender wheatgrass rhizome weight and length $(P<0.01$; Table 6). 
Table 5. Defoliation treatment effects on total root weight, length, and surface area of Nebraska sedge, slender wheatgrass, and birdsfoot trefoil plants.

\begin{tabular}{|c|c|c|c|c|c|c|c|c|c|}
\hline \multirow[b]{2}{*}{ Treatment $^{1}$} & \multicolumn{3}{|c|}{ Nebraska sedge } & \multicolumn{3}{|c|}{ Slender wheatgrass } & \multicolumn{3}{|c|}{ Birdsfoot trefoil } \\
\hline & Weight & Length & Surface area & Weight & Length & Surface area & Weight & Length & Surface area \\
\hline & g & $\mathrm{m}$ & $\mathrm{cm}^{2}$ & g & $\mathrm{m}$ & $\mathrm{cm}^{2}$ & $g$ & $\mathrm{~m}$ & $\mathrm{~cm}^{2}$ \\
\hline F-2 light & 6.58 & 108.1 & 2169 & 6.69 & 182.1 & 2990 & 9.54 & 170.4 & 2620 \\
\hline F-2 heavy & 6.57 & 119.7 & 2346 & 5.76 & 158.9 & 2827 & 11.08 & 195.1 & 3088 \\
\hline F-5 light & 6.92 & 106.4 & 2148 & 4.13 & 134.2 & 2327 & 9.90 & 184.0 & 2702 \\
\hline F-5 heavy & 6.09 & 97.5 & 2020 & 4.79 & 137.5 & 2264 & 7.55 & 136.0 & 2105 \\
\hline Hay & 6.45 & 116.2 & 2172 & 5.24 & 150.7 & 2505 & 9.66 & 171.6 & 2715 \\
\hline Control & 7.45 & 112.6 & 2316 & 5.83 & 171.6 & 2949 & 11.37 & 176.9 & 2804 \\
\hline Mean $( \pm \mathrm{SE})$ & $\begin{array}{c}6.68 \\
( \pm 1.15)\end{array}$ & $\begin{array}{c}110.2 \\
( \pm 18.8)\end{array}$ & $\begin{array}{c}2195 \\
( \pm 372)\end{array}$ & $\begin{array}{c}5.41 \\
( \pm 0.57)\end{array}$ & $\begin{array}{c}155.8 \\
( \pm 16.1)\end{array}$ & $\begin{array}{c}2643 \\
( \pm 281)\end{array}$ & $\begin{array}{c}9.85 \\
( \pm 1.31)\end{array}$ & $\begin{array}{c}172.3 \\
( \pm 21.7)\end{array}$ & $\begin{array}{c}2672 \\
( \pm 297)\end{array}$ \\
\hline Contrasts & & & & & $-(\operatorname{Pr}>F)$ & & & & \\
\hline Heavy vs. light & 0.59 & 0.91 & 0.92 & 0.87 & 0.60 & 0.70 & 0.76 & 0.58 & 0.83 \\
\hline Frequency 2 vs. 5 & 0.93 & 0.32 & 0.48 & 0.01 & 0.02 & 0.02 & 0.23 & 0.28 & 0.14 \\
\hline Hay vs. light & 0.76 & 0.54 & 0.96 & 0.85 & 0.77 & 0.66 & 0.97 & 0.97 & 0.88 \\
\hline Hay vs. heavy & 0.90 & 0.61 & 0.97 & 0.96 & 0.89 & 0.90 & 0.83 & 0.68 & 0.74 \\
\hline Control vs. all others & 0.29 & 0.82 & 0.59 & 0.41 & 0.23 & 0.20 & 0.21 & 0.84 & 0.63 \\
\hline
\end{tabular}

${ }^{1} \mathrm{~F}-2$ and F-5 refers to growing season defoliation frequency. Refer to Table 1 for timing and amount of defoliation.

Rhizome weight with less frequent defoliation $(\mathrm{F}-2 ; 3.55 \mathrm{~g} \cdot \mathrm{con}-$ tainer $\left.^{-1}\right)$ was greater than with more frequent defoliation (F-5; $2.42 \mathrm{~g} \cdot$ container $\left.^{-1}\right)$. Rhizome length under F-2 $(3.56 \mathrm{~m})$ was greater than that under F-5 $(2.44 \mathrm{~m})$. This treatment effect was also observed for total root weight, length, and surface area (Table 5) and could potentially affect the subsequent year herbage growth because of reduced capacity for nutrient storage and uptake. Rhizomes of both species tended to grow in a circular pattern at the container wall, indicating that the containers were limiting horizontal expansion.

Table 6. Defoliation treatment effects on rhizome weight and length of Nebraska sedge and slender wheatgrass plants.

\begin{tabular}{|c|c|c|c|c|}
\hline \multirow[b]{2}{*}{ Treatment $^{1}$} & \multicolumn{2}{|c|}{ Nebraska sedge } & \multicolumn{2}{|c|}{ Slender wheatgrass } \\
\hline & Weight & Length & Weight & Length \\
\hline & g & $\mathrm{m}$ & g & $\mathrm{m}$ \\
\hline F-2 light & 1.38 & 1.20 & 3.75 & 3.78 \\
\hline F-2 heavy & 1.36 & 1.13 & 3.34 & 3.34 \\
\hline F-5 light & 1.33 & 1.14 & 2.47 & 2.47 \\
\hline F-5 heavy & 1.48 & 1.28 & 2.37 & 2.41 \\
\hline Hay & 1.44 & 1.30 & 2.62 & 2.72 \\
\hline Control & 1.17 & 1.15 & 2.95 & 3.05 \\
\hline Mean $( \pm \mathrm{SE})$ & $\begin{array}{c}1.36 \\
( \pm 0.25)\end{array}$ & $\begin{array}{c}1.20 \\
( \pm 0.16)\end{array}$ & $\begin{array}{c}2.92 \\
( \pm 0.29)\end{array}$ & $\begin{array}{c}2.96 \\
( \pm 0.31)\end{array}$ \\
\hline Contrasts & & ----- (Pr & F) -------- & - \\
\hline Heavy vs. light & 0.87 & 0.80 & 0.38 & 0.40 \\
\hline Frequency 2 vs. 5 & 0.72 & 0.76 & 0.01 & 0.01 \\
\hline Hay vs. light & 0.75 & 0.50 & 0.17 & 0.27 \\
\hline Hay vs. heavy & 0.85 & 0.64 & 0.50 & 0.66 \\
\hline Control vs. all others & 0.16 & 0.71 & 0.90 & 0.76 \\
\hline
\end{tabular}

${ }^{1} \mathrm{~F}-2$ and F-5 refers to growing season defoliation frequency. Refer to Table 1 for timing and amount of defoliation.
The three species differed in the proportion of total belowground weight (roots and rhizomes) to aboveground herbage weight. Averaged over treatments, the combined root and rhizome weight of Nebraska sedge $\left(8.04 \mathrm{~g} \cdot\right.$ container $\left.^{-1}\right)$ was $165 \%$ of aboveground herbage production. This is consistent with Manning et al. (1989), who reported that in sedge-dominated communities, the majority of the biomass pool is belowground. Combined slender wheatgrass root and rhizome weight $\left(8.34 \mathrm{~g} \cdot\right.$ container $\left.^{-1}\right)$ was $93 \%$ of aboveground herbage production, and birdsfoot trefoil root weight $\left(9.85 \mathrm{~g} \cdot\right.$ container $\left.^{-1}\right)$ was $54 \%$ of aboveground production.

For riparian forage species, Clary and Leininger (2000) suggested leaving an adequate level of residual stubble height for maintenance of plant vigor and regrowth. However, in riparian communities, the indirect benefit of light to moderate defoliation on herbaceous vegetation may be more important for sediment control, stream bank stability, and protection of woody species. Generally, it is assumed that riparian graminoid forage species can be grazed more intensively than upland species because of their greater regrowth potential in a moist environment (Skinner 1998). Our results on Sandhills wet meadow for Nebraska sedge and birdsfoot trefoil would generally concur with this statement. More frequent defoliation did depress root growth of slender wheatgrass but did not affect aboveground production.

In general, the single year of defoliation treatments used in this study had a positive effect on aboveground growth but did not negatively affect root growth. Although some senescence was likely occurring in our nondefoliated control plants, our observations of significantly greater total aboveground production as a result of defoliation on slender wheatgrass and birdsfoot trefoil indicate that compensatory growth may have occurred. For Nebraska sedge, the haying treatment $(60 \%$ weight removed) also resulted in greater total aboveground production than light defoliation ( $10 \%$ weight removed). There are a number of internal physiological and environmental mechanisms that are thought to be associated with compensa- 
tory growth, some of which involve root growth (McNaughton 1983). Moderate to severe levels of defoliation usually result in immediate and short-term reductions in root growth (Jameson 1963) that might reduce the ability of a defoliated plant to regrow because both nutrient and water uptake would be reduced. In our study, both soil water and nutrients were likely sufficient throughout the growing season, supporting additional aboveground growth while maintaining root mass.

\section{MANAGEMENT IMPLICATIONS}

Abundant soil moisture in Sandhills meadows through the growing season is likely to buffer many of the possible negative effects of defoliation. Defoliation intensity did not affect aboveground production or root characteristics of the three species studied. Midsummer haying followed by fall grazing, which is the most common Sandhills meadow use regime, generally resulted in the greatest yield. The haying regime did not affect root growth characteristics compared to the control or to light or heavy defoliation in the spring and fall (F-2) or monthly (F-5) across the growing season. Although it did not affect aboveground production, monthly growing season defoliation should be avoided if slender wheatgrass is a dominant component of the community because of reductions in root growth. With monthly defoliation, it is possible that subsequent-year herbage production of slender wheatgrass and Nebraska sedge may be affected because of reduced capacity for water and nutrient uptake. Monthly defoliation or haying treatments resulted in maximum aboveground production of birdsfoot trefoil without affecting belowground biomass. This indicates that this species could be a persistent component of Sandhills meadows that are frequently grazed or hayed in combination with grazing.

\section{LITERATURE CITED}

Belesky, A. J. 1986. Does herbivory benefit plants? A review of the evidence. The American Naturalist 127:870-892.

Beuselinck, P. R., and J. J. Steiner. 1995. "ARS-2620" birdsfoot trefoil. Lotus Newsletter 26:34.

Beuselinck, P. R., E. C. Brummer, D. K. Viands, K. H. Asay, R. R. Smith, J. J. Steiner, and D. K. Brauer. 2005. Genotype and environment affect rhizome growth of birdsfoot trefoil. Crop Science 45:1736-1740.

Boyd, C. S., AND T. J. SVEJCAR. 2004. Regrowth and production of herbaceous riparian vegetation following defoliation. Journal of Range Management 57:448-454.

Chapin, S. F., III, AND M. SLACK. 1979. Effect of defoliation upon root growth, phosphate absorption and respiration in nutrient-limited tundra graminoids. Oecologia 42:67-79.

CLARY, W. P. 1995. Vegetation and soil responses to grazing simulation on riparian meadows. Journal of Range Management 48:18-25.

Clary, W. P., And W. C. Leininger. 2000. Stubble height as a tool for management of riparian areas. Journal of Range Management 53:562-573.

Coady, S. A., and R. T. Clark. 1993. Ranch management practices in the Sandhills of Nebraska: managing production. Lincoln, NE, USA: Agricultural Research Division, Institute of Agriculture and Natural Resources, University of Nebraska-Lincoln, Research Bulletin RB-318. 66 p.

Costa, C., L. M. Dwyer, X. Zhou, P. Dutilleul, C. Hamel, L. M. Reid, and D. L. Smith. 2002. Root morphology of contrasting maize genotypes. Agronomy Journal 94:96-101.

CRIDER, F. J. 1955. Root-growth stoppage resulting from defoliation of grass. Washington, DC, USA: US Department of Agriculture Technical Bulletin 1102. 23 p.
Derner, J. D., H. W. Polley, H. B. Johnson, and C. R. Tischler. 2001. Root system response of $\mathrm{C}_{4}$ grass seedlings to $\mathrm{CO}_{2}$ and soil water. Plant and Soil 231:97-104.

ELLISON, L. 1960. Influence of grazing on plant succession of rangelands. Botanical Review 26:1-78.

Enget, R. K., J. T. Nichols, and J. E. Brummer. 1993. A containerized technique for studying root systems. Journal of Range Management 46:467-469.

Engel, R. K., J. T. Nichols, J. L. Dodd, and J. E. Brummer. 1998. Root and shoot responses of sand bluestem to defoliation. Journal of Range Management $51: 42-46$.

Ferraro, D. 0., and M. Oesterheld. 2002. Effect of defoliation on grass growth: a quantitative review. Oikos 98:125-133.

FISK, M. C., S. K. SchmidT, AND T. R. SeAstedt. 1998. Topographic patterns of aboveand belowground production and nitrogen cycling in alpine tundra. Ecology 79:2253-2266.

Jameson, D. A. 1963. Responses of individual plants to harvesting. Botanical Review 29:532-594.

Jones, T. A., And D. C. Nielson. 1993. Spring-clipping response in Snake River and thickspike wheatgrasses. Agronomy Journal 85:94-97.

Kaul, R. B., D. Sutherland, and S. Rolfsmeier. 2006. The flora of Nebraska. Lincoln, NE, USA: School of Natural Resources, University of Nebraska-Lincoln. 966 p.

KILEY, D. K., AND R. L. Schneider. 2005. Riparian root through time, space, and disturbance. Plant and Soil 269:259-272.

Kunelius, H. T., L. B. Macleod, and F. W. Calder. 1974. Effect of cutting management on yield, digestibility, crude protein, and persistence of timothy, bromegrass, and orchardgrass. Canadian Journal of Plant Science 54:55-56.

Lamman, J. S. 1994. Effects of season and intensity of defoliation on two important montane riparian species [thesis]. Fort Collins, CO, USA: Colorado State University. $118 \mathrm{p}$.

Littell, R. C., G. A. Milliken, W. W. Stroup, R. D. Wolfinger, and 0. Schabenberger. 2006. SAS for mixed models. 2nd ed. Cary, NC, USA: SAS Institute, Inc. 813 p.

Manning, M. E., S. R. Swanson, T. Svejcar, and J. Trent. 1989. Rooting characteristics of four intermountain meadow community types. Journal of Range Management 42:309-312.

Martin, D. M., AND J. C. Chambers. 2001. Effects of watertable, clipping, and species interactions on Carex nebrascensis and Poa pratensis in riparian meadows. Wetlands 21:422-430.

McNaughton, S. J. 1983. Compensatory plant growth as a response to herbivory. Oikos 40:329-336.

Mislevy, P., J. B. Washko, and J. D. Harrington. 1977. Influence of plant stage at initial harvest and height of regrowth at cutting on forage yield and quality of timothy and orchardgrass. Agronomy Journal 69:353-356.

Moore, A. W., and H. F. Rhoades. 1966. Soil conditions and root distribution in two wet meadows of the Nebraska Sandhills. Agronomy Journal 58:563-566.

Mousel, E. M., W. H. Schacht, C. W. Zanner, and L. E. Moser. 2005. Effects of summer grazing strategies on organic reserves and root characteristics of big bluestem. Crop Science 45:2008-2014.

RatLIFF, R. D. 1983. Nebraska sedge (Carex nebraskensis Dewey): observations on shoot life history and management. Journal of Range Management 36:429-430.

SkINNER, Q. D. 1998. Stubble height and function of riparian communities. In: Stubble height and utilization measurements: uses and misuses. Corvallis, OR, USA: Western Regional Research Publication. Oregon Agricultural Experimental Station Bulletin 682. p. 29-46.

Sмiтh, G. G. 1976. Effect of vegetation on lateral migration of anastomosed channels of a glacial meltwater river. Geological Society of America Bulletin $87: 857-860$

Steele, J. M., R. D. Ratliff, and G. L. Ritenour. 1984. Seasonal variation in total nonstructural carbohydrate levels in Nebraska sedge. Journal of Range Management 37:465-467.

Volesky, J. D., D. C. Adams, and R. T. ClaRk. 2002. Windrow grazing and baled-hay feeding strategies for wintering calves. Journal of Range Management 55:23-32.

Volesky, J. D., W. H. Schacht, and D. M. Richardson. 2004. Stocking rate and grazing frequency effects on Nebraska Sandhills meadows. Journal of Range Management 57:553-560.

Weaver, J. E. 1930. Underground plant development in its relation to grazing. Ecology 11:543-557. 